\title{
Sacrificial human remains in an initiatory variant of the African waste heap (Kabye country, Togo)
}

Marie Daugey University of Liège

mdaugey@uliege.be

\begin{abstract}
Until the beginning of the twentieth century, in the Kabye country, some heads of enemies - those of men foreign to the group - were buried in a mound of earth referred to as hude, meaning 'manure'. In each locality, this mound is situated inside a wooded sanctuary where the spirit of the mythical founding ancestor resides. In order to understand this practice, this article examines how it fitted within the overall logic of the male initiation cycle, contextualising it in relation to past and present practices. Because it was a highly ambivalent element of the bush, the head of an enemy renewed the generative power of this original 'manure' prodigiously, so as to ensure the group's survival in their land. The burial of the heads of strangers appears to be an initiatory variant of other forms of mastery of the ambivalence of wild forces, entrusted in other African societies to the chief and his waste heap.
\end{abstract}

Key words: human remains, waste heap, sacrifice, initiation, Kabye, Togo

\section{Introduction}

According to testimonies collected by several European and Togolese researchers in the 1950s and 1960s, and according to the accounts that I heard more recently from a few Kabye ritual leaders, until the beginning of the twentieth century there was a ritual practice in Kabye country ${ }^{1}$ that consisted of burying the heads of men from outside the group - considered in their entirety as enemies - in a mound of earth up to three or four metres high. These mounds still exist today. In each locality ${ }^{2}$ they are built inside wooded sanctuaries where the spirit of the mythical founding ancestor resides. They are still used for ritual purposes: they are restored every five years as part of male initiation rites, and they can be used as receptacles for libations during seasonal agrarian rites, in the same way as the collections of stones and tree trunks in these sanctuaries, which serve as secondary altars dedicated to the founder. The mound is referred to by the term 'hude', meaning 'manure'. It therefore has the same name as the most common site of domestic waste: a manure pit which is found outside most houses. 
The burial of an enemy's head in this mound was carried out in a pre-colonial historical context where warlike practices were frequent. The conflicts of the Kabye were most often confined to their own groups, ${ }^{3}$ but they also confronted neighbouring groups such as the Nawdba. Their most formidable enemies were the Bariba, who regularly organised raids to take captives and goods from the Kabye. ${ }^{4}$ In 1898 German colonists entered the region, and after this date European 'pacification' gradually became established. However, armed clashes lasted until 1917, at which point the last Kabye revolts against the colonial power were repressed. ${ }^{5}$ It can be assumed that burials of enemy heads in 'manure' mounds of earth may have taken place up to this time. These burials occurred after the sacrifice of men from outside the group, which were carried out as part of male initiation rites. ${ }^{6}$

To understand the meaning of these treatments of human remains, it will therefore be necessary to relate them to the overall logic of the Kabye male initiation, which is still practised today and grants access to full adult status. Its form continues to be based on the traditional necessity to establish every male adult as a hunter and warrior. As we shall see, the incorporation of strangers' heads into the 'manure' mound is connected to a logic of appropriation of the resources contained in the space of the bush - with which strangers are associated - and which favour the renewal of the generative capacity of the land and of men. I shall therefore demonstrate that these human remains possess an ambivalent power: they appear to have a potential both for death and for life, which must be mastered for the benefit of the community. I also propose to interpret this practice as one particular form, within a segmentary lineage society, of a process aimed at domesticating wild powers, which is carried out in other societies of sub-Saharan Africa through a comparable device: that of the waste heap associated with the sacred power of a chief or a king. ${ }^{7}$

\section{The 'manure' mound of earth: a variant of the waste heap?}

The ritual mound of earth known as 'hude' ('manure') can be analysed as a metaphor for the ordinary manure pit that is present outside most Kabye houses, and which is also called hude. A Kabye house is made up of a set of round and rectangular huts, linked together by a surrounding wall. It has a shaded outdoor space called the 'tindee', meaning 'under the tree', where large flat stones are arranged under a tree to serve as seats for visitors and as a place of relaxation for the inhabitants of the house. The hude manure pit is situated close by. It is two to three metres deep and has a stone terrace. It holds household and plant waste, most of which is compostable, from cooking or the processing of certain crops, as well as the excrement of small livestock. During the rainy season (from May to October), goats and sheep are tied up and fed from the manure pit, and also feed it with their excrement. ${ }^{8}$ The organic fertiliser produced is spread in the fields closest to the houses. ${ }^{9}$

The ritual 'manure' earth mound is also found close to a dwelling, but it is an extra-ordinary dwelling, which is associated with mythical times. The mound is in fact located near two or three small huts which are considered to be the dwelling of the founder of the locality, and which house the main sacrificial altar dedicated 


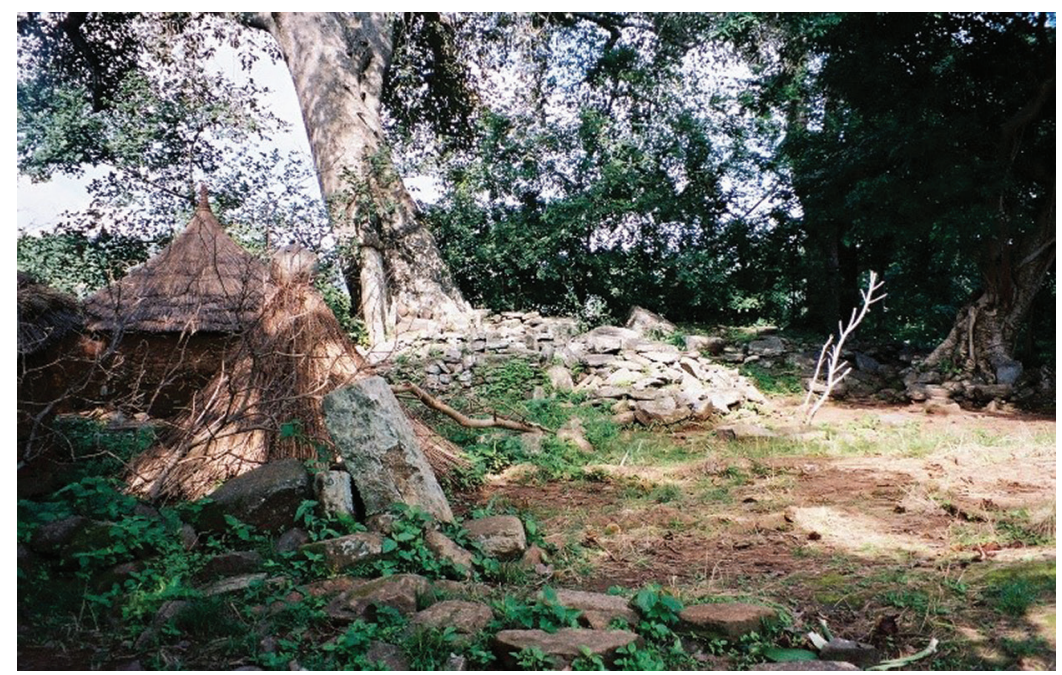

Figure 1 The dwelling of the first man, Lama, 2004 (Author's photo).

to this mythical ancestor (Figure 1). ${ }^{10}$ This first man is one of the deities of the territory (pl. agolima, sg. egolimiye), who influence the change of the seasons, the control of natural elements and the production of good harvests in a particular land. ${ }^{11}$ Although some of these territorial deities have a limited influence, the mythical ancestor who lives in the small forest where the 'manure' mound is located exerts his influence on the entire locality he founded, both on the land and on the people who consider themselves to belong to this place. The mound is therefore part of a cult system that represents a place of origin common to all the citizens of a locality (their shared home), and which contains a power that favours the well-being of the people who inhabit this land.

The location of the hude mound makes it possible to hypothesise that it represents a kind of original or generic manure. Apart from the fact that its shape is structurally and symmetrically opposed to the ordinary manure pit (Figures 2 and 3), which may indicate a continuity of meaning, ${ }^{12}$ its mound-like appearance is comparable to that of the waste dumps that usually rise near houses in other African societies (the use of a pit is rare). However, sometimes these dumps are more than just heaps of agricultural waste. They are sometimes seen as being subject to the influence of invisible entities: the ancestors of the house ${ }^{13}$ or bush genies. ${ }^{14}$ Their use is therefore surrounded by precautions, as is the approach to the Kabye manure pit: children are warned against retrieving objects that are thrown there, as a game, because this could be a trap laid by bush genies (alewa) who would like to force them into witchcraft. Waste heaps can also be places where a human lineage is attached or detached, during birth rites (placentas are buried there among the Kasena) ${ }^{15}$ or 


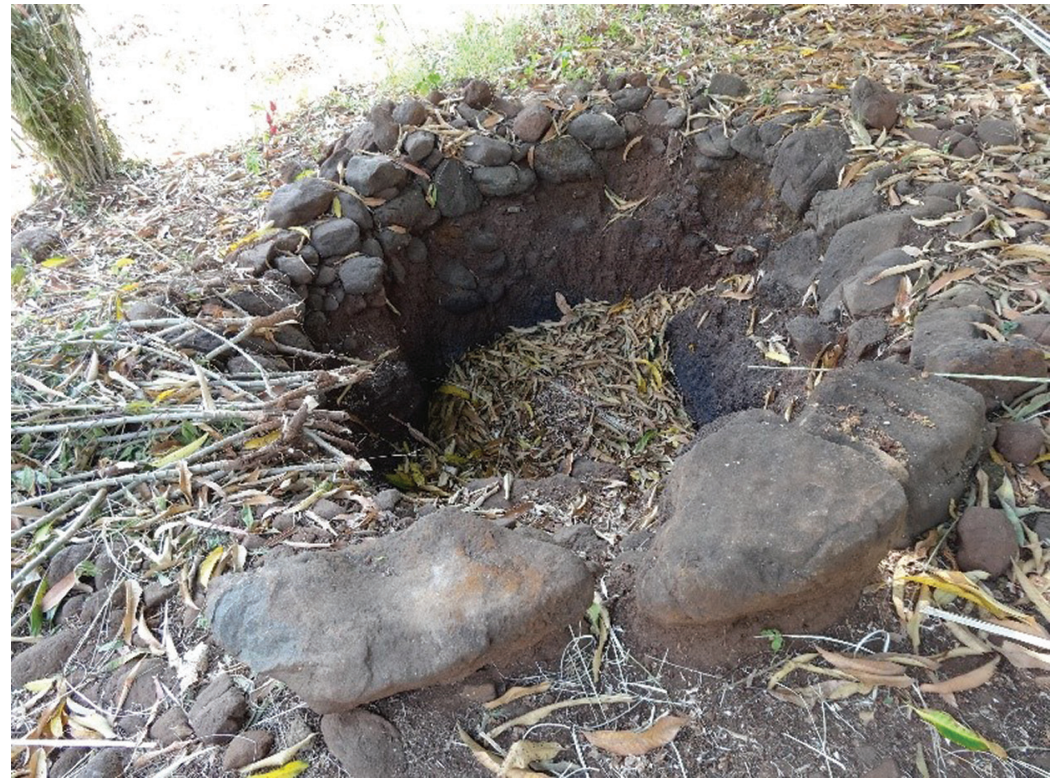

Figure 2 A manure pit, Soumdina, 2016 (Author's photo).

funeral rites (the temporary deposit of a corpse among the Bobo). ${ }^{16}$ While piles of ordinary waste can appear as frontier places between the visible and the invisible, between inhabited space and bush space, ${ }^{17}$ within chiefdoms, the waste heap that rises up in front of a chief's house can be a place of intensification of the relationship with the invisible and the bush. The elements that it contains, which are rarely mentioned by researchers, make it a place of deposit and continuity of a power that is both generative and dangerous, and even predatory. ${ }^{18}$ Among the Gizigua Bui Marva of Cameroon, the power on which the sacredness of the chief is founded depends essentially on the power of his waste heap. The energy it contains is due not only to the immense diversity of the elements that make it up, coming from all the homes within the chiefdom, but also to the addition of components that are considered to be intensely powerful, including the heads of wild animals, particularly 'panthers.' 19

The Kabye are a segmentary lineage society, traditionally without chiefs, ${ }^{20}$ and the right to a political voice is granted only to men who have completed their initiation (at around the age of thirty). The generational cohorts formed at the time of entry into the last initiatory grade can be assimilated to 'age classes' whose members together carry weight in decision making. ${ }^{21}$ Furthermore, male initiation is connected to the production of religious authorities - the high priests responsible for the worship of the agolima deities, called cojona (sg. cojo) - who have characteristics 


\section{Sacrificial human remains}

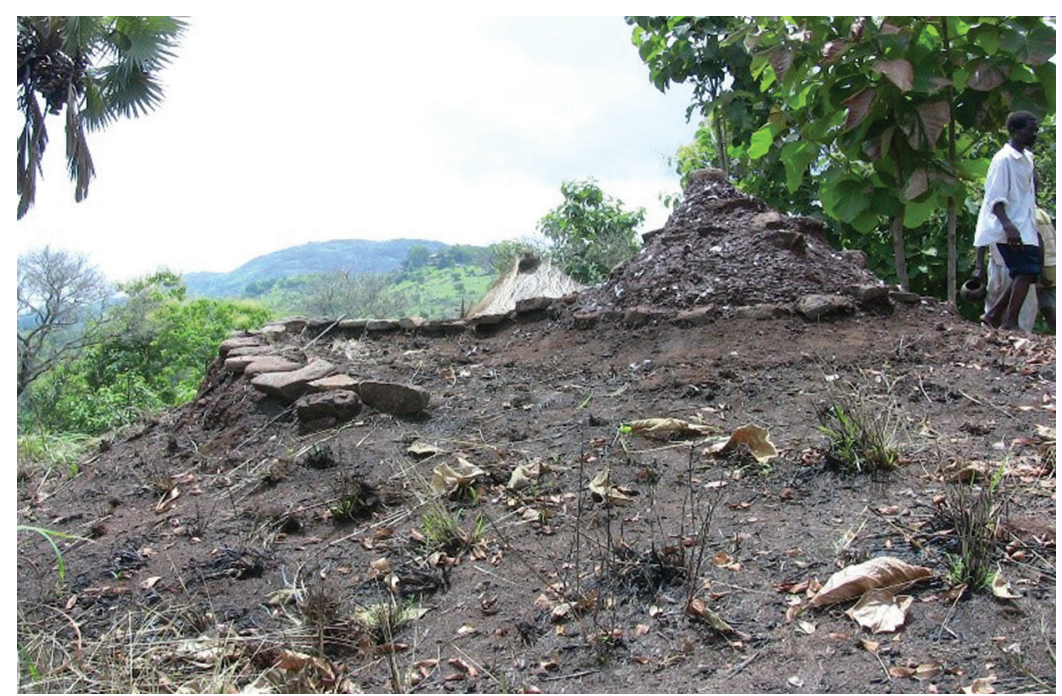

Figure 3 A 'manure' mound, Lassa, 2010 (Author's photo).

of sacred kings: ${ }^{22}$ their daily behaviour must be codified because their body and spirit are considered to have an influence on the natural elements (earth, rain, wind). The rules to be respected include the obligation to dress only in animal skins, not to greet anyone with a handshake and not to move away from the lands under their care. The responsibility for the current climatic disturbances is attributed to priests who no longer respect all the prohibitions connected to their role, which is to say the great majority of them, since they struggle to commit themselves fully to a life of heavy constraints. The initiatory institution contributes to the constitution of these characters. ${ }^{23}$ Male initiation begins at the age of eighteen and lasts for about ten years. It involves being successively integrated into four initiatory grades. At the entrance to the last grade, a young man who has been chosen to become a cojo will be seized and will undergo induction rites that identify him with an egolimiye. This will lead him, in the image of such a deity, to become one with the territory for which he is responsible and, formerly, to travel spiritually to the supreme god (Eso) in heaven. ${ }^{24}$ The rest of the novices continue the ordinary initiation rite by completing the construction of a relationship to the bush space, which is elaborated throughout the initiatory process. It is then that they are put in contact with the hude mound of earth, since the heads of strangers buried in this mound contain the most powerful of wild forces.

The examination of the way in which male initiates are currently brought into contact with the 'manure' mound, and then the explanation of how the burial of a human head was formerly part of the initiatory cycle, will provide initial elements for understanding the ambivalence of this mound and its contents. 


\section{A warlike connotation in the contact with the 'manure' mound of earth}

The novices are therefore brought into contact with the 'manure' mound during the rites of entry into the last initiatory grade, which are organised only every five years. This happens at the end of a collective journey, which is a sort of pilgrimage to the site representing the place of origin common to all the initiates of the same locality. The route followed by the groups of initiates - who are called kondona (sg. kondo) at this grade - varies according to their lineage. The members of each patrilineal group begin by meeting in the house where their patrilineal group was founded (called their 'big house'), then they successively cross several groves that house agolima deities who have made it possible for their patrilineal group to be grounded in a particular subdivision of the territory. Such a route, like other ritual itineraries that precede or follow it, is a way of presenting each person to the agolima deities on whom they depend. This itinerary therefore ends in the wooded sanctuary where the dwelling of the mythical founder and the 'manure' mound are located. Several hundred initiates then gather in this place, and advance in a line towards the mound. On this day, the kondona carry several iron objects: a necklace, an axe and a large bell with an external clapper (a large iron ring worn on the thumb). In Soumdina, they also carry in front of their faces a curtain of long, blackened cotton threads that were formerly made from enemy hair.

When the time comes, one of the high priests responsible for the ceremonies held in this sanctuary will go to the top of the mound to remove the woven straw covering (in the manner of the roof of a granary) that had been put on it when it was rebuilt a few days earlier. The kondona then climb to the top of the mound one after the other to ring their heavy bells, and in some places a little earth is thrown onto each one of them as they come down. Sometimes the climb onto the mound is accompanied by the rhythm of a large war drum which was once covered with the skin of enemy victims. ${ }^{25}$ This ritual sequence therefore involves immersing the initiates in a sensory environment (sonic, visual, tactile) which was once strongly imbued with enemy presence.

Anyone can come to watch the scene: men, women and children of all ages who belong to the family or friends of the kondona form a large crowd in front of the mound. Ringing the bell is a challenge. Initiates have to ring it above their head with one hand (Figure 4), which is not easy, given the weight and size of this object. Shouts of joy are heard from the crowd when the initiate succeeds. Conversely, a candidate's failure is met with a roar of disappointment. Such a setback does not have a serious impact on the continuation of the initiation, but it will be remembered and may later give rise to mockery implying the inferiority of the virility (abalito) of the one who failed. ${ }^{26}$ This virility is also measured in another way: those who possess the gift of clairvoyance reveal this quality by climbing up the hill and coming down backwards. They thereby signify their affinity with the domain of the invisible, which, as in other African societies, is characterised by practices that are the opposite of those in the visible world. Possessing this gift is, on the one hand, a sign of a predisposition to divination or witchcraft, and on the other hand, an indication 


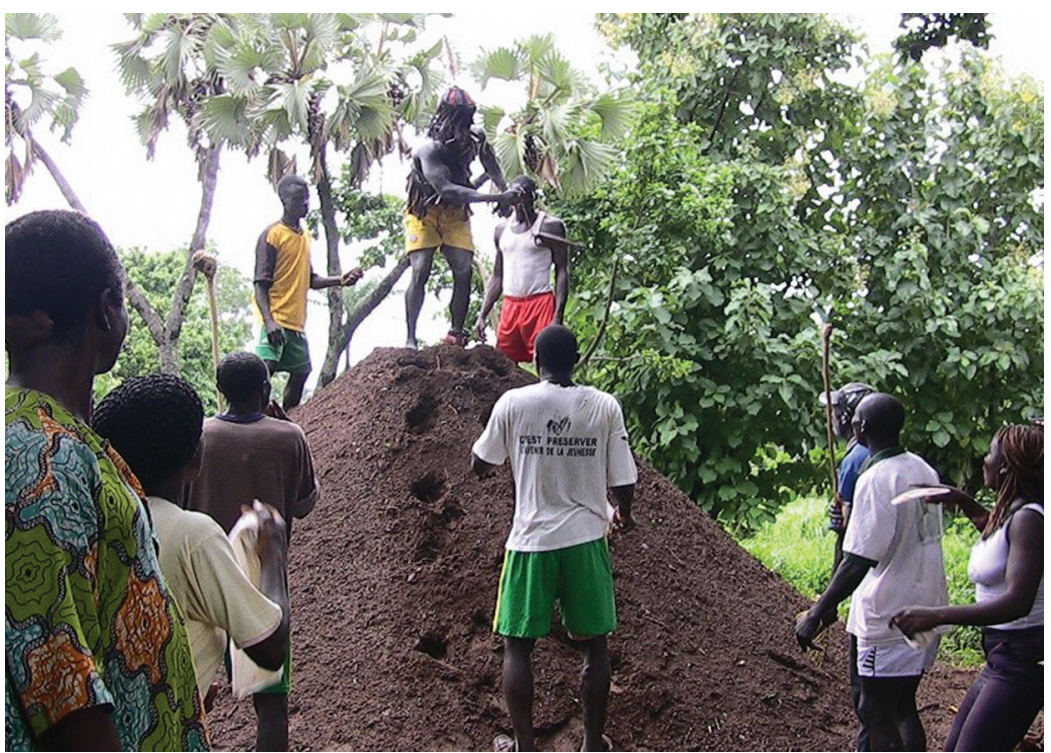

Figure 4 A kondo rings his bell at the top of a 'manure' mound, Soumdina, 2010 (Author's photo).

of a potential for war. Indeed, clairvoyance is a form of weapon which makes it possible to destabilise the enemy by the power of one's gaze, and is an attribute reserved for 'men among men', those who possess a superior masculine power. ${ }^{27}$

Other facts suggest that climbing the 'manure' mound has a warlike connotation. In Soumdina, the novice's sponsor - an individual guide who has completed his own initiatory journey - utters words of encouragement throughout the climb up the mound and, to signal that it is time to strike the bell, cries out 'break it!' However, this interjection is an incitement to 'frighten' or 'threaten' the other initiates (which is connoted by the verb nyazu, meaning 'to break'), 'as one must do in war', as some sponsors explained to me. R. Verdier also describes a practice that leaves no doubt as to this warlike purpose: at the end of the parade of initiates on the mound, a man who has completed his initiatory journey climbs to the top of the mound to brandish a bow and 'make the gesture of firing an arrow towards the enemy.28

While climbing the 'manure' mound is an opportunity to demonstrate a warlike aptitude or intention, the initiate's contact with the heads of strangers, and also sometimes with their hair, is a way of encountering the dangerous power of the enemy. Indeed, human heads are considered to be the seat of 'mystical' powers and clairvoyance, ${ }^{29}$ even after death. ${ }^{30}$ Moreover, accidentally ingesting a piece of the enemy's hair hanging in front of one's face would lead to serious illness and then death (Figure 5). Apart from the fact that hair, as in other societies, is considered to be the site of an accumulation of dirt,${ }^{31}$ ingesting it would provide the enemy with 


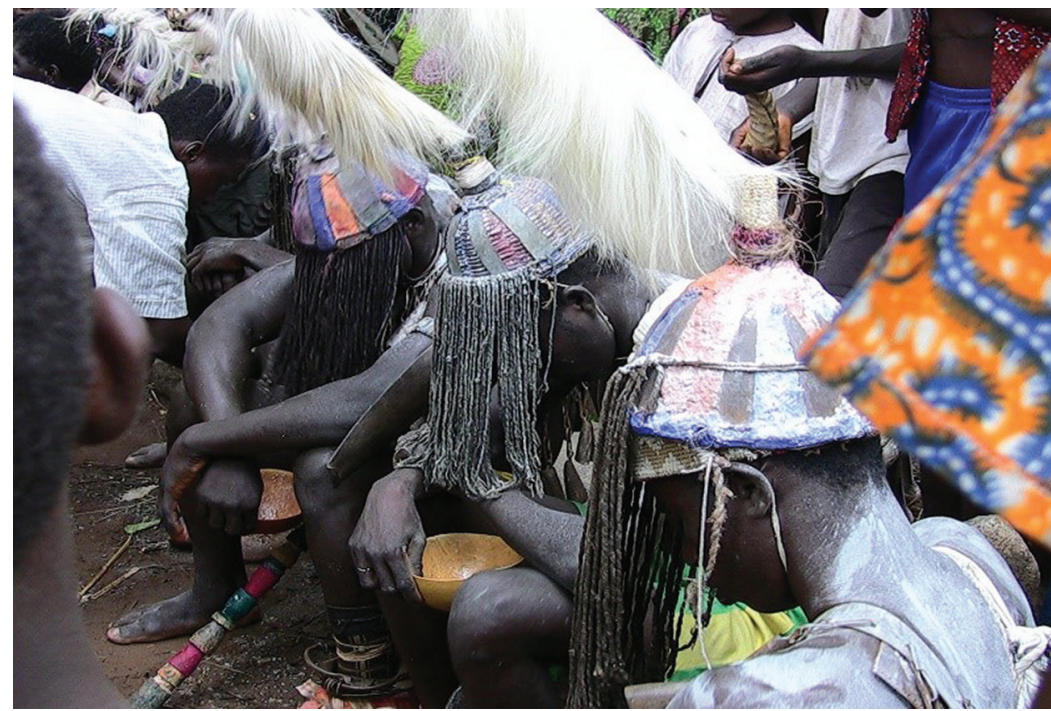

Figure 5 Kondona drink under threads of cotton that replace the old hair of enemies, Soumdina, 2010 (Author's photo).

the opportunity to spiritually interfere in the body of the initiate in order to unleash his vengeance, just as when a hunter ingests the hair of an animal prey. ${ }^{32}$

A mythical account describing the first implementation of male initiation also suggests that climbing the mound is a way of challenging the enemy. This myth presents the first kondona as performing particularly unbridled demonstrations of clairvoyance on the mound, which can be analysed as demonstrations of invincibility. ${ }^{33}$ One of the candidates climbed it 'sitting on the tip of a spear'; another 'climbed the mound after beheading himself and substituting a stone for his head. ${ }^{34}$ These acts of self-mutilation are reminiscent of those currently observable during the five-year habye rite, which consists of waging a war against 'death', that is, against a group of vectors of death, including enemies. This rite involves all clairvoyant men journeying across the territory to catch animals, visible or invisible, that represent death. Snakes, toads and scorpions are killed and thrown into a ceramic jar along the way, and then expelled from the territory. The 'death' that these animals represent corresponds to a set of pollutions resulting from transgressions of prohibitions, which accumulate in the soil in such a way that the fertility of the land is affected. These pollutions correspond to the blood and sexual secretions that are poured onto the earth, as well as to the souls trapped in the soil by sorcerers. Enemies are one of the vectors of 'death' because they have long caused bloodshed.

This ritual dance leads clairvoyants to stick arrows into their bodies or to cut themselves with a knife without drawing blood, and to bite into stinging plants or poisonous animals without feeling anything. There are sensational tales of the 
participants' exploits, such as the one about a man who cut open his belly, took out his intestines and put them back in again. Another man is said to have inserted an arrow in his urethra without feeling any pain. The participants thereby demonstrate the invincibility that their mystical power confers on them, in the manner of the very first candidates for the initiation in the mythical tale, who, through their exploits, seemed to measure themselves against the first enemy head that was buried in the mound.

The kondona play a major role in the habye rite, organised three months after their entry into this grade. In several localities, it is they who are responsible for capturing the animal most strongly associated with 'death' (a snake), and it is always they who carry the ceramic jar in which the animals that are vectors of death are stored during the ritual journey. At the end of the process, they run to the border with the neighbouring village to throw all the collected 'death' there. The contact of the kondona with the 'manure' mound therefore seems to prefigure the initiates' subsequent involvement in the rite of casting off death.

The encounter with the hude mound therefore appears as a mode of confrontation with the enemy and the mortal risk that the latter represents, in an attitude of defiance. However, as we shall now see, this enemy presence is not seen solely as a source of danger. It also guarantees the renewal of the reproductive capacities of the earth and of men.

\section{Heads from human sacrifices}

The presence of human heads in the 'manure' mound seems to be unknown to most Kabye. It was first mentioned by R. Verdier. He indicates that the mound was a 'mass grave' reserved for the heads of enemies; he speaks of it as a 'secret' revealed by an old informant. ${ }^{35}$ B. Cridel also writes: 'If any Bariba or Kotokoli fell into the hands of the Kabre, ${ }^{36}$ they would be martyred ... After having made the prisoner suffer, they cut off his head. It was then buried in the hude (manure), a mound on which the kondo climbs ... The body of the prisoner of war was dismembered, then cut up and the pieces distributed to each allied village. ${ }^{37} \mathrm{~K}$. Blanzoua also reports that in the locality of Bohou, the head of a stranger was buried in the mound at the time when it was restored. This happened a few days or even weeks before the initiates climbed the mound. According to him, in that locality this activity of restoration is still called 'the burial of the head of the stranger njoondou (kotokoli)'. He continues, 'nowadays, they symbolically pretend to bury a head that does not exist'. ${ }^{38}$ This act of restoration, which everywhere consists of pulling up the grasses on the mound and shoring it up, is now carried out by young men who are about to leave the initiatory cycle (having remained in the rank of kondona for five years) and/or by initiated adults. It can be assumed that, at least in Bohou, it was up to them to bury the enemy's head in the mound.

With these elements in mind, I often asked my interlocutors what was under the mound climbed by the kondona. Most of them replied, as if it were obvious, that there was nothing but earth underneath. Only two high priests, in the Lama region, spontaneously told me (without my asking) that there was formerly a practice of 
burying men's heads under the mound. They related this to the human sacrifices that were made in the past. Most of the high priests referred to this type of sacrifice in discussions about the ceremonies performed in the sacred groves under their care. These human sacrifices were made for the benefit of the most eminent deities of the territory, including the mythical ancestor who came from the sky. They took place every five years, shortly before the initiation of the kondona, and are now replaced by the sacrifice of bulls. They inaugurated a set of five-yearly rites that were coordinated with each other to reinitialise a new cycle of life development. ${ }^{39}$ Three categories of rites followed one another over a few months: (1) three to four human sacrifices in each locality, for the benefit of the most eminent deities of the territory (now replaced by bull sacrifices); ${ }^{40}$ (2) the rites of entry into the initiatory rank of the kondona; (3) the habye rite of the 'casting off of death'.

There is an interdependence between these three events. The sacrifices of bulls (and formerly of men) satisfy the deities, who will allow enough rain to fall, the earth to produce abundant crops and a new generation of men and women to be initiated. A failure to accomplish these sacrifices before the initiations is commented on in apocalyptic terms: the candidates for initiation would die. As for the formation of a new class of kondona, this is necessary for the implementation of the rite of the casting off of death, which frees the territory from the traces of 'death' scattered throughout the area. ${ }^{41}$

In addition to the five-yearly human sacrificial victims, any foreigner who entered Kabye country at any time was seen to pose a threat and was considered a potential enemy who had to be executed. If he was encountered near a deity to whom men were usually sacrificed, the high priests saw him as a sacrificial victim who had been brought by the deity himself. These human victims could come from a neighbouring ethnic group or from another Kabye mountain range.

Most of the high priests I met were in agreement that the body of a man who was sacrificed was cut up in the same pattern as sacrificial animals. The body was then shared among the different priests participating in the ceremony. The men whose particularly powerful virility gave them the necessary courage could come and eat this meat cooked on the fire. This gave them such warlike power that they could hit their enemies with a single arrow and the latter would die immediately. The different parts of the body that had not been consumed were either buried in the same hole in the wooded sanctuary where the sacrifice had taken place, or distributed among the officiants, who buried their share in another sacred grove for which they were responsible for worship. The victim's hair was shaved off to form the curtain that would later hide the kondona's faces. When there was a 'manure' mound at the site of the sacrifice, the victim's head would be buried there. ${ }^{42}$

Human sacrifices are perceived by today's high priests as having had an unparalleled effect on the fertility of the earth. They helped to renew the reproductive power of the agolima deities and would have made it possible to obtain extraordinary harvests. Several priests told me with conviction that 'when men were sacrificed the granaries overflowed!'. The custom of placing on top of the 'manure' mound a woven straw covering identical to that which forms the roof of an ordinary granary could be a sign that this mound contains a power linked to agriculture. 
Furthermore, the 'manure' mound is seen as playing a role in the transmission of reproductive ability from one generation to the next. The ascent of this 'manure' by the initiate meant that his mother would then become infertile. If the mother of a kondo is pregnant, the kondo must not climb to the top of the hill but must descend after climbing halfway, because to reach the top would lead to his mother experiencing a miscarriage. The climb to the top of the mound therefore brought an end to the fertility of the novice's mother, while at the same time instituting the novice in the status of official procreator. The word manure (hude) is sometimes used metaphorically to refer to sperm, which shows that there is an association between male fertility and manure.

The sacrificial treatment and burial of the enemy's head in the 'manure' mound therefore seems to convert part of the mortal value of these human remains into a reproductive value.

\section{The enemy: a bush inhabitant, a regenerating potential}

Resituating this burial of heads in relation to the overall logic of the male initiation cycle allows us to hypothesise that it is the enemy's connection to the bush space that gives it a regenerative quality for the fertility of the land and the fertility of men. ${ }^{43}$

Male initiation aims to construct men in the image of the most fearsome enemies, since men must possess the same qualities and aptitudes as their foreign enemies in order to be able to defeat them. These enemies are seen as emerging from the bush space, where wild animals live: they are conceived as half-human, half-animal beings, as 'man-eaters'. In a story that relates the origin of the male initiation rite, ${ }^{44}$ the initiation appears as a process that prepares the first-initiated boy for taking revenge on an ogre: a half-human, half-animal creature which had eaten several of his fingers when he was an infant. Once the child has grown up, his father, mother and maternal uncle subject him to a series of initiatory challenges, through which he acquires various qualities specific to wild animals. At the end of his initiatory journey, he can venture into the depths of the bush to find the ogre among the wild animals and chop off its head with an axe.

Male initiation therefore refers to a conception of the wild world, and the world outside the Kabye country, as harbouring anthropophagous creatures that are likely to enter the village to eat the population. This conception reaches back to a past era which is still described today as a time when members of certain neighbouring populations regularly came to attack the Kabye to take captives from among them or to draw sacrificial victims, whom they 'ate. ${ }^{45}$

For young men to eventually be able to confront bush dwellers, they must therefore gradually acquire certain properties associated with wild animals. By eating or wearing animal remains associated with the bush, the young initiates will gradually be identified with wild animals. When they reach the last initiatory grade, any person who comes across them must greet them by addressing them as 'lion!', 'leopard!' or 'ogre!', which completes their identification with the enemy. The kondona behave towards the village population in a cruel and implacable manner, as would a lion, an ogre or a slave raider. They impose their own rules, and to break them by behaving 
inappropriately towards a kondo is to risk being 'sold' by him, that is, suffering a heavy penalty or redeeming oneself by providing the initiate with a large quantity of sorghum beer or money.

Throughout the initiatory cycle, this new participation of the initiates in the wild world also places them in the position of intermediaries between the bush and the village, and even that of importers into the village of things from the bush that could bring a benefit for the rejuvenation of the land of the village. The rites of entry for each initiatory grade place the young people inside the sacred groves that shelter the deities linked to the foundation of the territory (the agolima). The initiates' presence in these places, while they are imbued with or carrying elements from the bush, creates a connection between the heart of the village and the bush, and this connection favours the control of the natural elements and the possibility of obtaining good harvests in a given territory.

I shall provide an insight into the way in which the initiates are gradually associated with the wilderness, and how they bring together the components of the bush with the agolima deities. In the first grade, the central act of initiation consists in the young men consuming dog meat. As in other societies, ${ }^{46}$ certain representations of the dog make it an animal associated with both the village and the bush. The dog has a form of intelligence and communication skills that enable it to live among humans while behaving like a wild animal: it eats excrement and practices incest; like a wild animal, it can become ferocious and run fast. The symbolic insertion of the initiates into the wild world therefore begins by putting them in contact with an animal that is 'halfway' between the village and the bush, as if to establish a gradation in the process of familiarisation with the bush.

Eating dog meat not only increases the virility of young people by increasing the amount of blood and semen in their bodies, but also imbues several qualities that are unique to the dog, such as alertness, the ability to run after game and the ability to cross the boundaries between the domestic and wild world. In Soumdina, they must demonstrate these abilities during a race that takes place during the last collective ritual hunt, and whose finishing point is far away in the bush. On the way back to the village, the initiates take leaves from a specific tree (laayoo) in the bush. These leaves are then deposited at the altars of certain ancestors considered to have power over rain. The high priests also deposit them in their fields, near where seeds are planted. These practices are supposed to bring about the heavy rainfall that will allow sowing (this takes place at the end of the dry season) and promote the healthy development of the cultivated plants.

In the second initiatory grade, young men are given a bow or arrows by their father or maternal uncle. ${ }^{47}$ These weapons symbolise the bush space. The possession of piercing weapons allows them to confront the most dangerous wild animals, but it also goes hand in hand with access to a certain control of the Harmattan wind, which is conceived as coming from the bush space. On the evening of their entry into this second initiatory grade, the initiates gather near a grove which shelters an egolimiye who is skilled in the fields of hunting, war and wind. This grove is referred to as 'In the bow' and represents distant bush space. The songs and cries that the initiates make in this place, and then in a part of the inhabited space, help to 'bring 
out' the Harmattan wind. Producing this wind is seen as a necessity: it will help to drive out various evils and diseases that threaten the community, and deposit on the ground a dust that is seen as favourable to crops.

At certain stages of the rites of entry into the last two initiatory grades, the initiates hang antelope skins on their chests or on their backs. In the northern part of the Kabye country, the long-horned skull of an antelope is attached to their head when they enter the last grade, so that the young men, like the legendary ogre of which they must become the equal, have the appearance of a half-human, halfanimal chimera. These different remains of wild animals are always seen as being the seat of the animal's soul. They come from animals killed in the hunt and for whom funeral rites have been performed, that is, rites that consist in overcoming the vengeful capacity of these animals, taming their powers and investing those powers in the village, which favours agriculture and the raising of livestock. These animal powers therefore contribute to the growth of animals and plants that, like them, are the result of a process of domestication.

Skins and skulls are involved in the transformation of the initiates by shaping their clairvoyant power in such a way that they become a weapon for confronting large wild animals and enemies. The wearing of these animal remains takes place in the course of ritual journeys that involve linking together the territory's deities, who are thought to constitute the respective origins of the different clans and patrilineal groups that make up the village community. These journeys are presented as helping to maintain the rainfall cycle. They echo a practice that takes place on the return from a successful hunt. In these cases, the bodies of the killed antelopes are transported to a series of agolima. The introduction of these bodies into sites representing the heart of the village is supposed to lead to rain showers. Here again, this practice is based on a domestication of the power of wild animals over natural forces, for the benefit of the village territory.

We therefore find, in the initiatory institution, an appropriation of the resources contained in the bush space, and a conversion of these resources into a power conducive to the development of human life.

Once it is situated in this initiatory logic, the burial of an enemy's head in a symbolic 'manure' mound appears to be the culmination of the process of connecting the territory's deities and the initiates with the distant bush. Because the head of an enemy is the most fearsome and powerful thing in the bush, it is also the most capable of renewing the forces of life in the village space. It constitutes the raw material of a symbolic manure which is necessary for the renewal of the earth and of human generations.

\section{The ambivalence of the enemy conceived through excrement}

We can clarify what is at stake in the symbolic association of the head of an enemy with a space of excremental waste material, by comparing the ascent of the initiates onto this 'manure' mound with the rite used in the village of Farende at the end of the initiation, by which the kondona were authorised to stop complying with the prohibitions specific to their status. This rite involved the kondona going in search 
of a stranger. They would bring him back to an egolimiye linked to hunting and war. There the stranger would be impaled with a large knife by the high priest in charge of the site, above a jar containing water mixed with crushed millet. Blood mixed with excrement would spill into the jar. Only those who had truly respected the initiatory prohibitions could ingest this mixture, using their left hand, which should not usually be used for eating, but for cleaning oneself after defecating. One had to abstain from consuming this mixture if one had not respected all the prescribed prohibitions during the initiation, at the risk of contracting an incurable disease, or even death. But to be able to consume such a mixture meant joining the category of men whose virility was seen as superior to others, and being able to fight in war without being afraid of enemies. ${ }^{48}$

This ingestion of the enemy's excrement appears to be an extreme version of the encounter with the enemy on the 'manure' mound (in the village of Farende, the kondona do not need to climb the mound). The comparison of these two practices confirms that excremental waste is a support for conceiving of the ambivalence of the power associated with the enemy's body: it represents a potential for both death and life. Treating the enemy's head as 'waste' is not a way to belittle or despise the enemy. On the contrary, it is a way of acknowledging its power and of trying to appropriate this power, in order to try to rise to the same level as that of the enemy. ${ }^{49}$

\section{Conclusion}

An analysis of the ancient Kabye practice of burying human heads in a 'manure' mound of earth leads us to understand that the representations associated with these human remains and this space of waste material are comparable to the customs and categories of thought associated with the chief's waste heap in other African societies, both those found geographically close to the Kabye and those in more distant locations. Among the Moose of Burkina Faso, the word tampure, which refers to the chief's waste heap, is understood in the sense of the 'base' or 'compost' of power, ${ }^{50}$ and the chief is sometimes referred to as a waste heap himself. This is not an insult, but a way of saying that he is the guarantor of the 'order of things' and the living conditions of the population. We find, in the reference to the idea of a base and compost, a similar semantic register to that used by the Kabye in reference to 'manure'. In the village of Farende (where there is no mound of 'manure'), the place where the first man touched earth after descending from the sky is sometimes referred to as his 'manure' (hude), in order to emphasise the primary and generative character of this place. Moreover, the 'manure' mound is found in sites that constitute the anchoring places of a community, and which contain the regenerative power necessary for the perpetuation of mankind on a portion of land. But we also find in this Kabye ritual 'manure', which feeds on 'lost' foreign bodies, another feature that is common to the concept of the waste heap, which is present in certain Voltaic societies too: that of catching things wandering in the bush (objects, animals, humans). This is the case of the waste heap of the Kasem chief, 'a powerful thing that "swallows" that which no longer has any attachment, ${ }^{51}$ and of the Samo 'master of the rain', who is himself compared to a chief but also to a waste heap, to which any object without owner 
must be handed over, as well as any stranger passing through the village ('by definition a prey or enemy'), who will then become his slave. ${ }^{52}$ Although the 'waste heap' always contributes to 'maintaining' the village and making it 'benefit' or 'grow', as the Samo say, ${ }^{53}$ its ambivalence is clearly conceived through an aptitude for predation, which derives from the connection with the wilderness. As exemplified by the Kabye case, but also that of the Guiziga Bui Marva of Cameroon, ${ }^{54}$ the wild world is in fact seen as being inhabited by threatening animal and human creatures, which are in themselves frightening and predatory, but which prove to be conducive to the renewal of life, as long as they are domesticated within 'waste' spaces by people who are at one with these spaces, whether this is a 'chief' or, as among the Kabye, initiatory cohorts. In these different societies, contrary to what has been observed in the canonical examples of sacred kingship, it is not necessary to eliminate and replace the bodies of chiefs or priests, who are seen as drivers of natural forces, as soon as they decline and weaken (in the canonical examples, regicide counteracts the risk that the king's physical decline will cause disasters: drought, epidemic, famine, etc.). For it is in the waste heap, sometimes conceived as an extension of the chiefs and priests themselves, that the principle of the continuity of power and cosmological equilibrium lies. ${ }^{55}$ The transformation of the body of the Other into a waste power, which is sustainable because it is renewable, seems to be an important support for thinking about this alternative. Among the Kabye, where power over the natural elements is widely distributed among the bodies of the high priests and the various categories of initiates, the burial of enemy heads in 'manure' is only the final stage in a process of the appropriation of wild forces, which guides the entire initiatory process and, in many ways, relays the sacred power of the priests.

\section{Acknowledgements}

An initial version of this text was published in French in an edited volume, A. Schmitt and E. Anstett (eds), Des cadavres dans nos poubelles: Restes humains et espaces détritiques de la Préhistoire à nos jours (Paris, Pétra Éditions, 2020). I thank the two peer-reviewers for their work and their advice, which helped to improve the text.

\section{Notes}

Translated by Cadenza Academic Translations.

1 There are just over a million Kabye in Togo. They are the second-largest ethnolinguistic group in the country. What they recognise as their territory of origin is a mountainous area of about $1,000 \mathrm{~km}^{2}$ located north of the town of Kara, in the north-east of Togo. Agriculture remains the main means of subsistence. The presence of the Kabye in this region dates back at least to the seventeenth century. See B. Tcham, 'Ethnonymie et histoire des origines: le cas des Kabiyè', in Actes des journées scientifiques de l'Université du Bénin (Lomé, Presses de l'U.B., 1990), pp. 56-73. 
2 I use the term 'locality' to designate the territorial and administrative subdivisions that correspond to the current cantons. In the Kabye language these localities are designated by their proper names, to which can be added the generic Kabye term 'teto', meaning 'land' or 'territory'. Each 'teto' is an important identity referent with its own dialect and ritual particularities.

3 The main circumstances that could trigger fighting between Kabye, within the same locality or between neighbouring localities, were disagreements over the boundaries of a field, the abduction of a woman and a quarrel over the appropriation of game during a hunt.

4 R. Verdier, 'Pouvoir, justice et vengeance chez les Kabiyé (Togo)', in R. Verdier (ed.), La Vengeance. Études d'ethnologie, d'histoire et de philosophie. Vol. 1: Vengeance et pouvoir dans quelques sociétés extra-occidentales (Paris, Cujas, 1980), pp. 201-11.

5 C.N. Kakou, Conquêtes coloniales et intégration des peuples: cas des Kabiyè au Togo (1898-1940) (Paris, L'Harmattan, 2007), p. 142.

6 The many similarities between the descriptions given to me by high priests, patrilineal elders or initiated young men living in different villages concerning the circumstances in which human sacrifices were made and the modalities of these practices leave me with little doubt as to their reality. These facts had been described to my interlocutors by their grandfathers, the oldest of whom had known the time of the wars and had told their descendants that they had taken part in these sacrifices.

7 The materials analysed here were collected during ethnographic missions conducted regularly in the Kabye country since 2004 in the localities of Soumdina, Lama, Lassa, and Farende.

8 In the rainy season a large part of the land is covered with crops. Livestock cannot be left free to roam the fields, as this would risk damage to the crops.

9 As well as the use of this manure to fertilise crops, there is also extensive use of chemical fertilisers.

10 In most localities, this founder is presented as having come down from the sky under the impulse of the supreme god, named Eso. Oral traditions do not seem to have preserved the trace of the population movements that preceded the settlement of the Kabye in their mountain region.

11 This category of deities also includes the children of the first man and his wife, viewed as the founders of the main clans and patrilineal groups, but also impersonal entities, which manifested themselves to the first humans in the form of a tree, a rock or a luminous form going back and forth between heaven and earth, thereby demonstrating very directly the mode of operation common to all the sub-categories of agolima: they go to the sky to take from it the resources (rain, seed, wind, etc.) necessary for human life on earth. The agolima can be compared with territorial deities present in other societies in the Voltaic cultural area, which are similarly manifested in prominent elements of the landscape (forests, rocks, hills). For a comparative analysis of this type of deities, see D. Liberski-Bagnoud, Les Dieux du territoire. Penser autrement la généalogie (Paris, CNRS/MSH Éditions, 2002). 


\section{Sacrificial human remains}

12 C. Lévi-Strauss, Le Totémisme aujourd'hui (Paris, PUF, 1962); J. Pouillon, 'Le structuralisme aujourd'hui', L'Homme, 164 (2002), 9-16.

13 Liberski-Bagnoud, Les Dieux du territoire, p. 72.

14 Y. Dévérin-Kouanda, 'De La Fertilité rurale à la nuisance urbaine: les difficultés variations culturelles du tampuure (pile d'ordures) en pays Mossi (région de Ouagadougou-Burkina Faso)', Géographie et cultures, 6 (1993), 121-34.

15 Liberski-Bagnoud, Les Dieux du territoire, p. 75.

16 J. Bouju and F. Ouattara, Une Anthropologie politique de la fange: conceptions culturelles, pratiques sociales et enjeux institutionnels de la propreté urbaine (Burkina-Faso) (Marseille, SHADYC/ Ouagadougou, GRIL, 2002), p. 84.

17 V. Baeke, 'Vers une anthropologie de l'excrément: le statut symbolique des lieux de défécation dans trois sociétés du Cameroun', Medische Antropologie, 1:2 (1999), 159-78.

18 Liberski-Bagnoud, Les Dieux du territoire, pp. 204-7. É. Guitard, “Le grand tas d'ordures est un instrument pour faire vivre la chefferie longtemps": Accumulation des déchets et royauté sacrée guiziga Bui Marva (Extrême Nord, Cameroun)', in É. Guitard and W. Van Beek (eds), Rites et religions dans le bassin du lac Tchad (Paris, Karthala, 2017), pp. 99-118.

19 Guitard, Ibid.

20 At the time of German colonisation, administrative chiefdoms were established within each 'canton'.

21 M. Daugey, 'Les Lions qui ne parlent pas. Cycle initiatique et territoire en pays kabyè (Togo)' (PhD thesis, EPHE, 2016), pp. 87-8.

22 J.G. Frazer, Le rameau d'or (Paris, Laffont, 1988); A. Adler, La mort est le masque du roi. la royauté sacrée des Moundang du Tchad (Paris, Payot, 1982).

23 Daugey, 'Les Lions qui ne parlent pas'.

24 A high priest spoke the words 'I am like Eso, I am like the earth' in July 2010, during a prayer accompanied by libations intended to make it rain.

25 R. Verdier, Le Pays Kabiyé. Cité des dieux, cité des hommes (Paris: Karthala, 1982), p. 80. This practice was also described to me with regard to another type of war drum, by a patrilineal elder who was the guardian of one of these objects.

26 According to Raymond Verdier, whoever 'stumbles' on the mound 'will be struck with misfortune. This suggests that there is still a risk in climbing the mound. See Verdier, Le Pays Kabiyé, p. 82.

27 On the journey taken before reaching this mound, the different groups of kondona may have already climbed another mound of earth, located in one of the groves that they have visited or close to their 'big house'. These hills mark the places of origin and territorial grounding of certain patrilineal groups. I do not know whether human heads were also buried there.

28 Verdier, Le Pays Kabiyé.

29 C. Piot, Remotely Global: Village Modernity in West Africa (Chicago: The University of Chicago Press, 1999).

30 We also find this idea concerning the heads of wild animals, which remain inhabited by the vengeful spirit of the dead animal. 
31 E.R. Leach, 'Magical Hair', Journal of the Royal Anthropological Institute of Great Britain and Ireland, 88:2 (1958), 147-64.

32 The idea of a murder victim taking revenge through spiritual intromission into the body of his killer is present in neighbouring societies. S. Dugast, 'Meurtriers, jumeaux et devins: trois variations sur le thème du double (Bassar, Togo)', Systèmes de pensée en Afrique noire, 14 (1996), pp. 175-209; D. Sewane, Le souffle du mort. La tragédie de la mort chez les Batãmmariba (Togo, Benin) (Paris, Plon, 2003).

33 R. Verdier, 'Les structures socio-religieuses des Kabré du Nord-Togo' (PhD thesis, Sorbonne, 1962), p. 23.

34 This feat places the initiate in a position of superiority over the enemy victim whose head is in the mound, since decapitation cannot kill him.

35 Verdier, 'Les structures socio-religieuses des Kabré, p. 97.

36 The term Kabre is in use in the northern part of the 'Kabye/Kabre country'. This is linked to a difference in dialect, whereby the phoneme /r/ changes into / $/$ / almost systematically in the southern area.

37 B. Cridel, 'Notes sur les guerres tribales et l'arrivée des Allemands', Documents $d u$ Centre d'Études et de Recherches de Kara (1968), pp. 249-51.

38 B. Kao, Anthropologie de la parenté Kabiyè: la valeur archéologique de l'intronisation du kondo (Lomé, 2007), p. 103. The repairs I attended did not give rise to any semblance of head burials.

39 Five-year periods, known as wasi (sg. waa), are used as a unit of measurement of time and ages in Kabye country.

40 This is an estimate based on the information collected in the localities I surveyed.

41 In other societies, we find a similar concordance between the holding of initiations and the restarting of the ritual cycle, which is considered to be the basis for maintaining social organisation. Cf. J.-C. Muller, La Calabasse sacrée: initiations rukuba, Nigeria central (Grenoble, La pensée sauvage; Montréal, Presses universitaires de Montréal, 1989); J.-F. Vincent, Princes montagnards du Nord-Cameroun. Les Mofu-Diamaré et le pouvoir politique (Paris, L'Harmattan, 1991).

42 Some of the groves in which the 'secondary' mounds of earth are found, marking the foundation sites of the patrilineal groups, are among the places where human sacrifices were made. I do not know whether the heads of victims were buried under these mounds.

43 For an in-depth study of male initiation, see Daugey, Les Lions qui ne parlent pas.

44 J. Bassari Ebia, 'Légende traditionnelle sur l'origine des classes d'âge chez les Kabrè, Bulletin de l'enseignement supérieur du Bénin, 9 (1969), 77-83.

45 On the issue of the slave trade, which was thought by its victims to be a form of anthropophagous predation, see G. Guille-Escuret, Sociologie comparée $d u$ cannibalisme. 1. Proies et captifs en Afrique (Paris, Presses universitaires de France, 2010), pp. 228-34.

46 E. Copet-Rougier, 'Le Jeu de l'entre-deux. le chien chez les Mkako (Est-Cameroun)', L'Homme, 28:108 (1988), 108-21.

47 Practices differ between the northern and southern part of the Kabye country. 
48 On human excrement as a bearer of a vital power, see J.-P. Colleyn, 'Sur le chemin du village: l'initiation au koro minyanka', Journal de la société des africanistes, 45:1-2 (1975), 115-25; M. Houseman, 'Les artifices de la logique initiatique', Journal des Africanistes, 54:1 (1984), 41-65.

49 This analysis concerns the symbolic aspect of this practice. It cannot be excluded that this treatment was conceived by those who inflicted it as being depreciatory.

50 M. Izard, Moogo. L'émergence d'un espace étatique ouest-africain au XVIe siècle (Paris: Karthala, 2003), p. 145.

51 Liberski-Bagnoud, Les dieux du territoire, p. 206.

52 F. Héritier-Izard, 'La Paix et la pluie. Rapports d'autorité et rapport au sacré chez les Samo', L’Homme, 13:3 (1973), 121-38.

53 Ibid.

54 Guitard, “Le grand tas d'ordures"”.

55 Guitard highlights this principle among the Guiziga Bui Marva (ibid.). S. Dugast has shown that among the Bassar, neighbours of the Kabye, the absence of the practice of killing the chief is also due to the identification of the latter with a waste heap, but according to a different logic. The dirt and evils that threaten the well-being of the population accumulate in the chief's hair and gradually wear out his body, but the periodic shaving of his head restores his strength and brings back prosperity. S. Dugast, 'Rites et organisation sociale: l'agglomération de Bassar au Nord-Togo' (PhD thesis, EHESS, 1992), pp. 827-51. 